\title{
COMPLEX EMERGENCIES AND THE CRISIS OF DEVELOPMENTALISM
}

\section{Mark Duffield}

\section{INTRODUCTION}

The background to this article lies in the historic shifts taking place in the global economy and their wide ranging social and political implications. The proces's of regionalization and the formation of linked but contending North American, West European and East Asian economic blocs are very important. There is a lurking fear that these developments are having the unintended effect of locking out and marginalizing nonbloc areas of the world (Oman 1994). In parts of Africa, the Middle East, East Europe and the former Soviet Union, a systemic economic crisis has emerged which has rolled back the modest development gains of past decades (Sideri 1993). Income disparities between the richest and poorest countries have grown ever wider (UNDP 1992). Consequently the number of interna tional economic migrants has steadily increased to an estimated 60 million today (Pellerin 1993). Myrdal's (1957) dictum of 'circular and cumulative causation' where growth in one area is synonymous with the decline of another is back on the agenda.

It is important to note, however, political instability has also become an entrenched part of the global scene. A stark indicator of this trend has been the steady rise in the number of ongoing wars: from
10 in 1960 to around 50 today (Gantzel 1994). Each year more have started than have ended and wars are also lasting longer. It is significant that the increase is mainly due to the burgeoning number of internal as opposed to interstate wars. The level and spread of insecurity are unprecedented in modern times. There are now around 20 million refugees globally with similar numbers of internally displaced people (Welsh 1993).

Political instability has also changed its geographical centre of gravity. It has begun to reflect the process of regionalization. Following the end of the Cold War, political tensions have decreased in East Asia and Latin America. In contrast, they have tended to concentrate and scale new heights in parts of Africa, the Middle East, East Europe, the Caucasus and Central Asia (Suhrke 1993). In 1993, for example, there were $26 \mathrm{UN}$-designated 'complex emergencies' affecting 59 million people (UN 1993). Apart from Haiti, it is significant that all were in the Africa-Eurasia zone.

As external causes have ceased to explain, the character of internal war has also begun to change. The previous, ideologically driven nationalist or socialist wars of liberation have been superseded.

Figure 1: Ongoing wars, 1945-1992

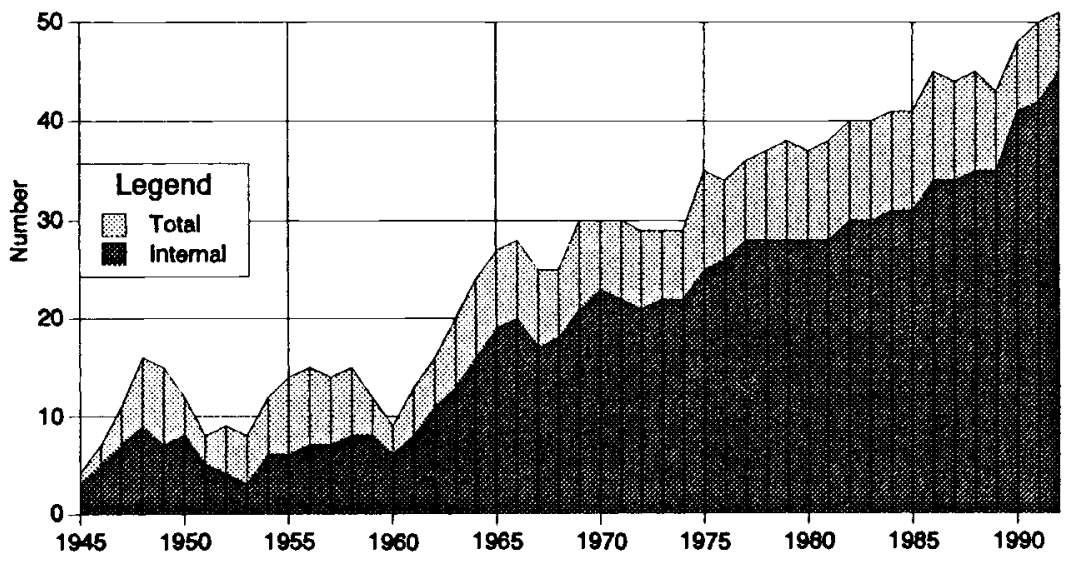

Source Gantzel, 1994 
Emerging in their place are resource wars that lack a clear social programme (Duffield 1991). In response to systemic crisis, proactive and nonconventional socio-economic formations have emerged. These are often ethnically structured and of a predatory or fundamentalist nature. Rather than a temporary occurrence, violence has become an important adjunct of economic and political survival in landscapes increasingly lacking alternatives (Keen 1994). More recent has been the emergence of ethno-nationalism and internal war within and on the periphery of the former Soviet empire (Schierup 1993). In the past, political violence was usually linked to a process of state formation. Some commentators now argue that the world has entered a phase of insecurity associated with state disintegration (Kaldor 1993; Suhrke 1993).

The UN and the international aid apparatus were shaped in a more certain world. They are now strained to the limit in the face of new complex emergencies, characterized by unprecedented levels of abject poverty, political insecurity, conflict, state disintegration and population displacement.

\section{COMPLEX EMERGENCIES AND THE CRISIS OF DEVELOPMENTALISM}

Complex emergencies challenge conventional views on development. Developmentalism rests on the assumption of the universality of social progress (Norgaard 1994). Development is a normative process of becoming: a series of interconnecting movements leading from poverty and vulnerability to security and well-being. It is part of the myth of modernity. That is, the certainty that shared progress is the normal and long-term direction of all social change. For several decades, the modernist paradigm has dominated the international aid apparatus. Simultaneously, however, this apparatushas been powerless and uncomprehending in the face of growing systemic crisis and political fragmentation, a trend that is the antithesis of the developmental world-view. The stage has now been reached where transcending the developmental crisis is the main challenge for progressive aid policy. Understanding complex emergencies is central to this task.

The term complex emergency emerged in Africa in the late 1980s. It gained wider currency with the Gulf War. For the UN, a complex emergency is a major humanitarian crisis of a multi-causal nature that requires a system-wide response. Commonly, a long-term combination of political, conflict and peacekeeping factors is also involved (UN 1993: 23). Apart from a new peacekeeping element, this is not an original or apt conception. In many respects, the multi-causal model has become interchangeable with an earlier category of man-made emergency. Both multi-causal and man-made emergencies are usually defined in opposition to implicitly monocausal natural disasters.

Despite this attempted contrast, the multicausal definition of a complex emergency does not effectively distinguish it from a natural disaster. It has long been recognized that even natural disasters, such as droughts or floods, are themselves complex social and ecological phenomena (Kent 1987). Socalled complex emergencies are essentially political in nature: they are protracted political crises resulting from sectarian or predatory indigenous responses to socioeconomic stress and marginalization. Unlike natural disasters, complex emergencies have a singular ability to erode or destroy the cultural, civil, political and economic integrity of established societies. They attack social systems and networks. Humanitarian assistance itself can become a target of violence and appropriation by political actors who are organic parts of the crisis. Complex emergencies are internal to political and economic structures. They are different from natural disasters and deserve to be understood and responded to as such.

\section{THE LIMITED NATURE OF RELIEF ACTIVITY}

The international relief apparatus has also failed operationally to distinguish complex emergencies from natural disasters. For example, the relief programmes in Angola and Somalia usually concentrate on the delivery of basic survival commodities and services. Despite being political emergencies, such programmes have their operational origins in the response to floods and droughts. That a degree of military protection for the delivery system exists in a few places does not invalidate this point. Moreover, there are big differences between what could be called weak and strong state crises in Africa and the Balkans respectively. Despite this, humanitarian relief programmes in these two regions have also assumed similar organizational forms (Duffield 1994a). The logic of relief activity derives from a natural disaster model that pays little attention to social or political factors. 


\section{Figure 2: Global disaster relief as a proportion of global ODA}

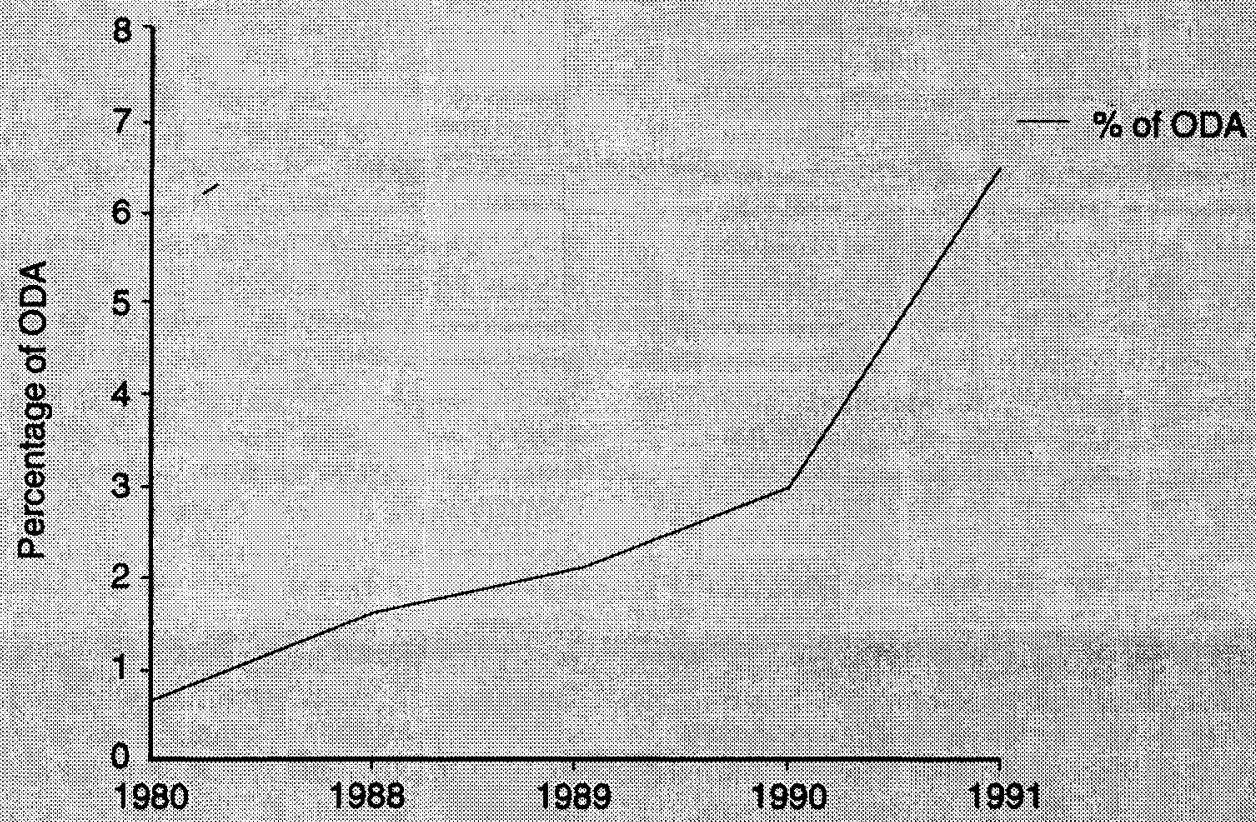

Source: Borton, 1998

It is common to regard this one-dimensional humanitarian response to political crisis as a problem of relief policy. This is tantamount to seeing relief and development as essentially separate practices. A cursory examination reveals this not to be the case. Relief is a developmentalist concept. Analytically and institutionally development has always been the dominant of the pair. Developmentalism is incapable of understanding political crisis as anything but a short-term or abnormal occurrence. Despite the increasing number of internal wars and their growing longevity, even conflict is still regarded as a transitory setback. In consequence, relief has been forced into a series of temporary administrative, personnel and financial compromises: the spurious image of the external natural disaster hasbeen pressed to provide a template for all relief situations, even social collapse and political violence.

\section{THE CHANGING CHARACTER OF AID FLOW}

One notable effect of the collapse of the Cold War has been the decline in strategic importance of the West's former Third World allies (Griffin 1991). Partly as a result, even before the end of the 1980s, total development aid had begun to stagnate and decline. Reflecting the systemic crisis, however, the reverse is the case with emergency spending (Borton 1993). This has been increasing noticeably since the 1980s. UN agency, EU, bilateral donor and NGO budgets graphically illustrate this point. For Britain's Overseas Development Administration, for example, the proportion of its aid budget spent on relief has increased from 2 per cent in the early 1980s to 11 per cent in 1991-92. Similar figures for UNICEF are from 7 per cent in 1987 to 23 per cent in 1993 (UNICEF, nd). EU's spending on external humanitarian relief increased more than five times between 1990 and 1993, that is, from 114.3 million to 605 million ECUs (European Commission 1994).

General figures are more difficult to come by (Borton 1993). A probable underestimate is that around $\$ 4$ billion, or about 7 per cent of total overseas development assistance (ODA) is spent on relief expenditure (Figure 2). One also has to bear in mind the escalating cost of UN peacekeeping. This is $\$ 3.2$ billion a year and rising (Elliot 1994). 
Following the stagnation of development assistance, there is a concern that increased expenditure on relief is at the expense of development. Within complex emergencies, however, the global trend usually presents itself as a complete substitution. In many parts of Africa, for example, development budgets have collapsed and humanitarian assistance is the only substantial aid being received. Importantly, the substitution of relief expenditure represents both a quantitative and qualitative decline in the character of aid. Although global relief expenditure is rising, there is marked underfunding of individual programmes and growing competition between emergencies (Keen 1992). Furthermore, despite the comprehensive physical, institutional and social destruction that can result from a protracted political crisis, food aid remains the main response.

\section{ACTUAL RELIEF VERSUS HYPOTHETICAL DEVELOPMENT}

One effect of the systemic crisis is the growing interest in 'linking relief and development',' relief-development strategies', or 'relief to development continuum' ideas (Ross, et al. 1994). An important feature of what can be called the linking debate is that by a process of inversion, rather than the modernist paradigm, it is relief that is usually cast as needing reform. In relation to UNDP's advocacy of a development continuum, for example, emergencies are seen from a modernist perspective, that is, as temporary interruptions to the process of linear development (UNDP 1994). However, because of increased humanitarian expenditure, there is a concern that relief itself is becoming a threat to social progress:

If conceptualized, planned and implemented in isolation [relief] will replace development and breed long-term dependencies, undermine indigenous coping strategies and increase vulnerabilities.

\section{(UNDP 1994:1)}

UNDP has missed the wood for the trees. It is not relief practice per se that is the problem but the systemic crisis that it ineffectively addresses.

The linking debate is primarily an argument over resources, a defensive move by an institutional interest which fears for the object of its existence: stable societies that can sustain socioeconomic improvement. The shift in aid flow toward emergency spending has accentuated this crisis.
Developmentalists have been forced to argue their centrality in a space that, in the past, was willingly abandoned to relief. Three decades ago, many now crisis-ridden countries had a functioning civil and social administration, a transport system and a modest, but real, economy. If they were not able to achieve sustainable development then, it is questionable if it is possible now given, the loss of these advantages.

There are two conceptual difficulties with the linking debate. First, it is unable to come to terms with the reality of permanent emergency. Waiting for a new dawn of resumed development is hampering research and practical action which needs to be taken now. The simplistic treatment of conflict as an irrational occurrence, as the antithesis of development, is a case in point. Consequently, self-sustaining war economies remain little understood. Second, since relief work has never been taken seriously, the extent to which donor policy has already effected a de facto accommodation with permanent emergency has largely been missed. Instead of trying to link relief to a hypothetical state of development, it is better to examine this actually existing accommodation.

\section{ACCOMMODATION WITH PERMANENT EMERGENCY}

The accommodation with protracted crisis is a contradictory structure. At one level the aid apparatus has been plunged into a period of unprecedented institutional change and policy flux. Complex emergencies have become a forcing house of changing North-South relations. Simultaneously, however, they have elicited a limited relief response. The quality of aid has been reduced, the pattern of intervention is uneven, military humanitarianism has a dismal history, and so on. This suggests that appeasing Northern constituencies rather than tackling the crisis may be the main impact of so-called humanitarian intervention.

The systemic crisis and the substitution of relief for development leads to the following proposition. Despite the short-term nature of relief activity and its origins in natural disaster, it has come to play an unexpected role in North-South relations. In the post-Cold War era, humanitarian aid is the North's principal means of political crisis management in a now marginal South. 
Initial attempts to analyse the accommodation with permanent emergency argued the historic importance of the formation of donor/NGO safety-nets during the latter part of the 1980s (Duffield 1992). The following is a brief but more comprehensive appraisal.

\subsection{The Cold War era: neutrality and the acceptance of conflict}

The period between Biafra in the late 1960s and Ethiopia in the mid 1980s was an important phase of development. During this time, the UN was constrained by sovereignty and limited by its mandate to working with recognized governments. In cases of internal war, except for the International Committee of the Red Cross, this often meant that the humanitarian needs of peoples in contested areas were not met.

Some NGOs attempted to fill the humanitarian deficit in contested areas. Typically, new NGOs or NGO consortia, often church based, emerged in relation to controversial cross-border or cross-line type programmes (Davis 1975). The illicit nature of these activities reinforced an earlier tradition that humanitarian relief must be neutral, that is, eschew politics and only provide externally monitored, basic relief items (Duffield and Prendergast 1994). To have engaged in wider development activities could have been construed as political solidarity. It would have compounded the problem of legitimacy at a time when sovereignty was paramount. While deploring conflict, concerned NGOs had little choice but to take the historic step of developing nonmandated programmes in war situations. In contrast, during the Cold War, the UN seldom intervened in a political crisis without an agreed cease-fire (Goulding 1993).

\subsection{The mid 1980s: donor/NGO sub-contracting} In Africa, the Cold War was all but over by the mid 1980s (Clough 1992). This ushered in a period of formative development. A historic shift of donor funding away from states saw a general expansion of NGO involvement in relief work (Borton 1993). Changing donor policy meant that previously illicit cross-border operations gained de facto recognition at the expense of nation-state sovereignty. The enhanced humanitarian role of NGOs was synonymous with the increasing development of nonmandated donor/NGO subcontracting relations (Korten 1990). From the Horn, safety-net systems spread to protracted crises in other parts of Africa. By the end of the 1980s, the position of NGOs as relief implementors was well established. For most of this period, internal contractual relations were usually of an ad hoc or informal nature (Duffield 1992). The idea of NGO flexibility owes much to this phase.

\subsection{The late 1980s: negotiated access}

At the close of the 1980s, there emerged the first UN mandated cross-border or cross-line type operations. South Sudan, Ethiopia and Angola are examples (Minear 1991; Duffield 1994a). Sometimes known as 'corridors of peace', these programmes mark a historic turning point for the UN. Following the path of independent NGOs, it too accepted the need to work in unresolved conflict situations (Higgins 1993). Post-Cold War euphoria and the belief that humanitarian assistance could itself promote peace helped this transformation (UNICEF 1991).

The basis of these operations was negotiated access. That is, the UN securing the agreement of warring parties to the movement of neutral humanitarian aid. Negotiated access programmes also saw the beginnings of the UN's integrated approach to complex emergencies. That is, establishing a formal division of labour between the UN specialist agencies according to their traditional roles with one taking a coordinating lead.

The new demands thrust upon the UN helped expose the lack of implementation capacity within its specialist agencies. Therefore, negotiated access programmes also created the outline of a new UN/ NGO relationship. The UN would secure access, funds and provide coordination while NGOs would carry out the actual relief programmes. Compared to earlier donor/NGO subcontracting, the new UN/ NGO safety-net exemplified the trend towards more formal contracts and instruments of affiliation.

By mandating previously illicit cross-border type operations, negotiated access represented a further erosion of sovereignty. Such programmes also radically changed the operational equation for NGOs. The choice became whether to join an UN integrated programme or remain outside. Some NGOs, such as MSF(F) and the large American agencies, often decided to operate independently of integrated programmes. Importantly, the continuation of ICRC and donor/NGO safety-nets alongside emergent UN negotiated access operations, represented an increase in policy instruments available to donors. 


\subsection{The Gulf War: military humanitarianism and donor agencies}

Rather than pushing accommodation in a new direction, the Gulf War built on earlier trends. Importantly, it threw the limitations of the existing interface into contrast. UN agencies and NGOs did badly in the humanitarian crisis arising from the conflict (UN 1991). Moreover, the specific conditions of the war had shown the limitations of negotiated access. The principle of using military personnel to protect a UN mandated relief operation was established (Roberts 1993). Following Kurdistan, ad hoc variants have appeared in Bosnia, Somalia and Rwanda. Importantly, however, in relation to the first two, protection has often also incorporated a policy of internalising or containing refugee flows (Douglas Stafford 1993).

Of equal significance were UN agency and donor developments. Concerning improving coordination within UN integrated programmes, in 1992 the Department of Humanitarian Affairs (DHA) was established. The DHA has restated the centrality of the UN/NGO relation. Through consolidated appeals, it has also attempted to put emergency funding on a more secure base. As for donors, the EU and some bilateral governments were persuaded to establish their own operational emergency capacity. This was a result of both the poor performance of NGOs and the increasing donor time and expenditure devoted to relief (Pooley 1991). Apart from the EU, several governments, including the UK's, have become humanitarian agents (ODA, 1991).

\subsection{The current period: the normalization of violence}

Military humanitarianism has already begun to wane. The immense political difficulties encountered in Bosnia and Somalia has prompted caution. Rather than a blue print for a New World Order, it is probable that military protection for humanitarian programmes will remain exceptional. Protection, however, is not an intrinsic feature of the accommodation. A trend of greater significance has been a continuing operational evolution of UN negotiated access.

Post-Cold War optimism has disappeared. Within UN negotiated access operations, the emphasis has been on further separating politics from humanitarian relief. The chief policy instrument for this has been the development of formal rule-based physical security and delivery systems. NGOs affiliate based on agreed neutrality and codes of conduct. The operational core of negotiated access is the collective UN/NGO distribution plan. Such plans are usually drawn up on a weekly of monthly basis by the lead UN agency. They are cleared in advance with the warring parties and aid is delivered according to set times and corridors. This type of formal system is presently running in Angola, Bosnia and South Sudan (Duffield 1994b). While having military protection and the internalization of displacement as appendages, Bosnia, for example, is essentially a negotiated access programme.

Compared to the late 1980 s, mandated negotiated access is now more sophisticated. One consequence is that humanitarian assistance has become closely integrated with the dynamics of violence. It is increasingly common for UN integrated programmes, even NGOs, to employ ex-military personnel as security advisors. In many complex emergencies the infrastructure now exists for aid to ebb and flow with the level of fighting. This is an unprecedented situation.

Ordered war economies have given way to more fragmented patterns of violence and asset stripping. For many movements and factions, the control and manipulation of relief assistance has become an important aspect of the political economy of conflict (Scott-Villiers 1993). Local power relations have been altered and new ones fostered. It has placed aid workers in positions of great risk and uncertainty (Jean 1993). More have been killed in the past couple of years than in the preceding decade.

\section{KEY ASPECTS OF THE ACCOMMODATION}

Negotiated access is the main response to unresolved conflict in the South. This accommodation has produced an unprecedented integration of socalled neutral humanitarian assistance with the dynamics of violence. There are several interconnected trends.

The North has become conditioned to increasing levels of dislocation and political violence in the South. Independent NGOs initially forged the principle of nonmandated humanitarian work in ongoing conflict. This was later given a major boost by donor governments in the mid 1980s at the expense of nation-state sovereignty. By the beginning of the 1990s, the UN had also accepted the necessity of working in unresolved political crisis. One result of 
this institutional accommodation is that today's 50 or so ongoing wars, rather than being seen as unprecedented, are experienced as somehow normal. To gain attention at all, political crises have to plumb ever increasing depths of breakdown or barbarity.

While systemic crisis has become normalized, the number of policy instruments available to donors has increased. Donor governments now have the choice, for example, of either working through the ICRC, independent NGOs or NGO consortia, integrated UN operations, or even becoming operational themselves. In other words, they have found significant operational and political flexibility at a time when total aid budgets are declining. If any development gains have been achieved, they are here. Tragically, however, as Bosnia has shown, donor flexibility has contributed to the erosion of ideas of collective international responsibility for the Southern predicament. The UN Charter and Geneva Conventions have been weakened (Childers 1993). In their place narrow perceptions of national interest, or calculations based on media exposure or domestic political advantage have become the arbiters of engagement.

Flexibility, and the consequent erosion of collective responsibility in international relations, has been helped by the emergence of a private and competitive NGO sector (Borton 1994). NGO financial and media dependency, plus their ability to work in a variety of situations, has been important in allowing donor governments to shape humanitarian programmes around national interests, a major change that many NGOs appear unable to contemplate let alone accept.

\section{CONCLUSION}

Rather than a debatable resumption of sustainable development, more realistically the structure of accommodation will continue to evolve and consoli- date. Since many of its features are based on ad hoc institutional arrangements and UN resolutions, the main direction will be increasing formalization.

To a large extent this has already occurred in relation to contractual relations and general codes of conduct (Minear and Weiss 1993). From an institutional perspective, to overcome the short-termism that has compromised relief in the past, changes in funding, management structures and personnel regimes are underway. Emergency programming is increasingly being seen as a long-term issue: relief is being professionalized. Progressive policy has begun slowly to move away from supporting transitory populations to attempting to work with indigenous structures in the thrall of protracted crisis. More controversially, it is possible that integrated relief programmes will take on a formal quasi-governmental function in a few locations.

Relief alone, however, will not eradicate permanent emergency in the South. Apart from serious questions of adequacy and appropriateness, the present accommodation leaves untouched the global dimensions of the systemic crisis sketched above. Indeed, the international predominance of free market ideology suggests that regional polarization will continue to grow. Making lasting in-roads will depend on whether a new political consensus can be built by aid agencies, religious bodies, NGOs and donors. Such a consensus would need to reestablish a sense of collective international responsibly for poverty and violence in a now marginal South. Never before has there been such a need for sustained public action and an unflinching support for international mandates.

This consensus should be linked, moreover, to a new ethics of working in protracted political crisis. Ways of engaging the complex reality of internal war have to be found. In this respect, the notion of neutrality requires thorough critique. Solidarity rather than neutrality has to be the guiding hand.

\section{REFERENCES}

Borton, J., 1994, NGOs and relief operations: trends and policy implications', London: ODI

1993, 'Recent trends in the international relief system', Disasters, Vol 17 No 3: 187-201, September

Childers, E., 1993, 'In a Time Beyond Warnings: Strengthening the United Nations System'. London: Catholic Institute for International Relations
Clough, M., 1992, Free at Last? US Policy Toward Africa and the End of the Cold War. New York: Council on Foreign Relations

Commission of the European Communities, 1994, 'Humanitarian aid: Annual Report 1993.' Brussels: Commission of the European Communities, February 16

Davis, M., 1975, (ed.), Civil Wars and the Politics of International Relief, New York: Praeger Publishers 
Douglas Stafford, M., 1993, 'New strategies for refugees in the 1990s.' Refugees, Vol 91: 13, February

Duffield, M., 1994a, 'Complex political emergencies: an exploratory report for UNICEF with reference to Angola and Bosnia'. Birmingham: School of Public Policy

1994b, 'An account of relief operations in Bosnia', Relief and Rehabilitation Network, Network Paper 3

1992, 'Famine, conflict and the internationalization of public welfare.' in M. Doombos et al. (eds), Beyond the Conflict in the Hom: The Prospects for Peace, Recovery and Development in Ethiopia, Somalia, Eritrea and Sudan, The Hague: Institute of Social Studies: 49-62

1991, 'War and famine in Africa.' Oxfam Research Paper No 5, Oxford: Oxfam Publications

Duffield, M., and Prendergast, J., 1994, Without Troops or Tanks: Humanitarian Intervention in Eritrea and Ethiopia. Trenton, NJ: Africa World Press Inc/Red Sea Press Inc

Elliot, L., 1994, 'Debts fetter world's police force', The Guardian, p14, May 13

Gantzel, K. J., 1994, 'War in the post World War II world: empirical trends, theoretical approaches and problems on the concept of 'ethnic war'. Paper presented at Symposium on Ethnicity and War, San Marino: Center for Interdisciplinary Research on Social Stress

Goulding, M., 1993, 'The Evolution of United Nations Peacekeeping'. Intemational Affairs Vol 69 No 3: 451-464, July

Griffin, K., 1991, 'Foreign aid after the Cold War', Development and Change, Vol 22: 645-685

Higgins, R., 1993, July, The new United Nations and the former Yugoslavia', International Affairs, Vol 69 No3: 465-483

Jean, F., 1993, (ed.), Life, Death and Aid: The Médecins Sans Frontières Report on World Crisis Intervention, London: Routledge

Kaldor, M., 1993, 'Yugoslavia and the new nationalism.' New Left Review, No 197: 96-112, January

Keen, D., 1994, The Benefits of Famine: A Political Economy of Famine and Relief in Southwestem Sudan, 1983-1989, Princeton, NJ: Princeton University Press

1992, Refugees: Rationing the Right to Life - The Crisis in Emergency Relief, London: Zed

Kent, R. C., 1987, Anatomy of Disaster Relief: The International Network in Action. London: Pinter

Korten, D. C., 1990, Getting to the 21st Century: Volutary Action and the Global Agenda, Connecticut: Kumarian Press

Minear, L., et al., 1991, Humanitarianism Under Seige: A Critical Review of Operation Lifeline Sudan. Trenton: Red Sea Press
Minear, L., and, Weiss T.G.,1993, Humanitarian Action in Times of War, Boulder: Lynne Rienner

Myrdal, G., 1957, Economic Theory and Underdeveloped Regions, London: Gerald Duckworth

Norgaard, R. B., 1994, Development Betrayed: The End of Progress and a Coevolutionary Revisioning of the Future, London: Routledge

ODA, 1991, 'Immediate help for disaster victims', News Release, London: Overseas Development Adminstration, August 14

Oman, C., 1994, Globalization and Regionalization: The Challenge for Developing Countries, Paris: OECD Development Centre, January

Pellerin,H.,1993, 'Global restructuring in the world economy and migration: the globalization of migration dynamics.' International Joumal, XLVII:240-254, March

Pooley, Chairman of the ad hoc group, 1991, 'Report by the ad hoc group on emergency humanitarian aid', Brussels: European Commission, November

Roberts, A. 1993, July, 'Humanitarian war: military intervention and human rights', Intemational Affairs, Vol 69 No 3: $429-449$

Ross, J., Maxwell, S., and Buchanan-Smith, M., 1994, 'Linking relief and development: report on a workshop held at the Institute of Development Studies, University of Sussex, 28-29 March 1994', Brighton: IDS, April

Schierup, C. U., 1993, 'Prelude to the inferno: economic disintegration and thé political fragmentation of Yugoslavia', Balkan Forum Vol 1 No 8: 80-120, March

Scott-Villiers, A., Scott-Villiers, P., and Dodge, C.P., 1993, 'Repatriation of 150,000 Sudanese refugees from Ethiopia: the manipulation of civilians in a situation of conflict', Disasters Vol 17 No 3: 202-217, September

Sideri, Sandro, 1993, 'Restructuring the post Cold War world economy: perspectives and prognosis',Development and Change, Vol 24 No 1: 7-27, January

Suhrke, A., 1993, 'A crisis diminished: refugees in the developing world', International Journal, XLVIII: 215-239, March

UN, 1991, 'An analysis of the UN system's response in Turkey to the humanitarian problems resulting from the Gulf crisis', United Nations Office of the Resident Coordinator of the UN System's Operational Activities for Development in Turkey

1994, 'Strengthening of the coordination of humanitarian emergency assistance of the United Nations', Report of the Secretary General, A/48/536. New York: United Nations, October 18

UNDP, 1992, Human Development Report: 1992, Oxford: University Press 
1994, 'Position paper of the working group on operational aspects of the relief to development continuum', New York: UNDP, January 12

UNICEF, 1991, 'From ceasefire to elections (June 1991 December 1992): implications and strategies of UNICEF/ Angola', Luanda: UNICEF

\section{UNICEF}

nd, 'UNICEF response to emergencies.' New York:

Welsh, D., 1993, 'Domestic politics and ethnic conflict', Survival, Vol 35 No 1: 63-80 